\title{
RESOURCE CURSE THESIS: NIGERIAN EXPERIENCE OF OIL THEFT
}

\section{C.O. Okwelum (Ph.D)}

\author{
Delta State Polytechnic, Ozoro. Tel: 08075684274
}

Cite this article:

C.O. Okwelum (2021), Resource Curse Thesis: Nigerian Experience of Oil Theft. African Journal of Law, Political Research and Administration 4(1), 70-84. DOI: $10.52589 / A J L P R A-$ FD6HEQ0T.

\section{Manuscript History}

Received: 12 April 2021

Accepted: 30 April 2021

Published: 25 May 2021

Copyright $\odot 2020$ The Author(s). This is an Open Access article distributed under the terms of Creative Commons Attribution-NonCommercialNoDerivatives 4.0 International (CC BY-NC-ND 4.0), which permits anyone to share, use, reproduce and redistribute in any medium, provided the original author and source are credited.

\begin{abstract}
The emergence of the crime of oil theft and illegal refineries is not sudden but the realization of its negative economic impact on the national economy and the business of multinational oil companies have taken the State and the companies by storm shortly after the Presidential proclamation of amnesty in 2009 was configured to fob-off militancy in the Niger Delta of Nigeria. This paper attempts to address the resource curse of oil theft and illegal refineries in the region from a legal theoretical framework running through the various sociolegal theories through which the crime can be viewed and explained. It panders to the critical theoretical school which attributes the causes mainly to State and multinational oil company failures in infrastructural development and social responsibility commitments to the indigenous minority ethnic communities of the Niger Delta region of Nigeria rather than the orthodox school which blames the militants for 'greed not grievance' instincts. It employs the analytical, historical and doctrinal methods in presenting and analyzing its research data and in drawing its conclusions. The paper finds that two major and mutually repugnant tendencies in the explanation of the crime crop up from the research records. The one pursued by State actors which is anti-recognition and vehemently opposed to oil theft and local refineries and which calls for their bombardments and annihilation through the instrumentality of military strike force, JTF, and the other which is purveyed by nonState actors which is pro-oil theft that believes that the best approach ought to be condonation, legal regulation and mainstreaming of the phenomenon as part of an indigenous building block of development. This latter perspective discountenances the employment of brute force in the confrontation of the phenomenon and is thus recommended in this paper.
\end{abstract}

KEYWORDS: Oil Theft, Legal Regulation, Brute Force, Illegal Refineries, Social Responsibility, Crime 


\section{INTRODUCTION}

Oil has become a serious topic of academic discussion, largely due to the developmental prospects it may confer and the links it has with conflict. Resource curse refers to the negative effects natural resources can have on the economy, governance and levels of conflict largely in the global south. A theory developed by Richard Auty, Jefferey Sachs and Andrew Warner, the literature on 'resource curse' has suggested that natural resources such as oil can create violent competition and protracted conflict over access to resource wealth ${ }^{1}$ and that natural resources wealth is negatively correlated with economic growth in a diverse set of extractive economies. ${ }^{2}$ Even politically, research has found, in strong support of the resource curse thesis, that oil helps when it is found in a nation after it has attained democracy and hurts when it is found in a nation before it attains democracy. ${ }^{3}$

The central thesis of this paper is that one of the variants of resource curse or paradox of plenty in the delta of Nigeria is oil theft and the development of an illegal alternative economy built on it that has found expression in the emergence, and destruction by the state, of well over 6,000 illegal refineries in the delta as at 2013 and yet, thousands more are surging up on a daily basis from the ashes and smokes of the bombardments. What is the cause? The curse is so potent and prurient that even the state has almost given up both the moral and legal capital and courage to confront the scourge, appealing instead to the international community for bare cooperation and mere understanding on the basis of the economics of demand and supply framework of international crime. By acquiring a life of its own, the crime has developed to the level of its being operated 'underground' in the Delta to avoid the attention of the state's military patrol teams (Joint Military Task Force), bombardment outfits and air surveillance exercises as suggested by Parliament of the United Kingdom.

\section{Resources and War}

According to Akpobibibo Onduku, the link between environmental resources and the outbreak of international conflicts has been recognized for decades. ${ }^{4}$ Put differently, the connection between the finding of oil on a piece of land and the generation of conflict and war over that piece of land is close both at communal, state, national and international levels. For Osita Obierika the strategic importance of petroleum compelled Adolf Hitler to occupy Poland and Romania very early in World War 11 because of the oil refineries in the countries ${ }^{5}$ and the control of oil bolstered US military and economic might and enabled the US and its allies to win both world wars and the cold war. ${ }^{6}$

\footnotetext{
${ }^{1}$ Joe Sutcliff, Military in the Niger Delta: Petro-Capitalism and the politics of youth. www.e-ir.info/2012/06. June 25, 2012.

2 The paradox of plenty, Niger Delta Politics: Dispatches on Security in Nigeria's Oil Region. http://nigerdeltapolitics.word. January 10, 2012.

${ }^{3}$ When oil helps and when oil hurts. Niger Delta Politics: Dispatches on Security in Nigeria's oil Region. http://nigerdeltapolitics.word. January 11, 2012.

${ }_{4}$ Akpobibibo Onduku, Environmental conflicts: The case of the Niger Delta. Department of Peace Studies University of Bradford, United Kingdom. www.waado.org. November 22, 2001.

${ }^{5}$ Osita Obierika, Geopolitics and strategy of petroleum. The Nige rian experience. www.vanguardngr.com September 27, 2012.

${ }^{6}$ David S. Painter, Oil and the American century. The Journal of American History, Vol. 99, Issue 1. June, 2012. www.m.jah.oxfordjournals.org. Retrieved on December 2, 2013.
} 
Writing on the 2012 China-Japan conflict, Kevin Voigt in Dangerous Waters: Behind the Islands dispute ${ }^{7}$ states: 'although nationalistic ardor on both sides of the dispute has brought the current situation to a bail, national interest in the territory can be traced to a 1969 United Nations Geological Survey that contains this tantalizing line: 'A high probability exists that the continental shelf between Taiwan and Japan may be one of the most prolific oil reserves in the world.' Also, under its South China-sea lies a potentially huge reserve of natural gas and oil. A Chinese estimate suggests as much as 213 billion barrels of oil reserves outside of Saudi Arabia, according to the US Energy Information Administration.

The same scenario played out in Congo, Liberia and now, Kenya. In fact, the Congo and Liberia situations were notorious, worst case scenarios, conflict mineral wars that need not arrest and detain our attention further here. In the recent case of Kenya, the state had to revoke all prospecting and mining licenses granted during the first quarter of 2013 after complaints about the issuing process surfaced. The licenses in question had been issued in 'a hurry and without transparency' and had to be reviewed in each case to determine their nature and benefit to the country. ${ }^{8}$

The Kenyan authorities promised to review the laws regulating the sector which as at 2013 included more than 300 local and foreign firms either searching for minerals or in small scale production. Richard Hamilton observed that traditionally Kenya did not have a large mining sector but the recent discoveries had encouraged a sea rush of local and international speculators. Among the finds along the coast worth billions of dollars were titanium and niobium with properties that make steel more heat resistant and useful in an oil pipeline, jet engines and MRI scanners. The International Monetary Fund (IMF) had claimed that the licenses and new mining contracts were shrouded in secrecy. With the review, royalties were to go up from $3 \%$ to $10 \%$ gross sales value. ${ }^{9}$

The irony of it all has been expressed by Dailey Kate: Conflict minerals that help fuel war in the Democratic Republic of Congo and elsewhere often end up in the most popular electronic gadgets. $^{10}$

\section{Oil theft in the Nigerian civil war}

In Nigeria, the earliest evidence of oil's role in civil conflict can be traced to the Nigerian civil war. It was clear that the majority of Nigeria's early oil resources were in Igboland and this was perhaps the galvanizing force behind the secessionist strike. The Federal government of Nigeria on the other hand equally realized that Biafra's independence would certainly have cut the nation's oil wealth production into half and therefore decided to come down fiercely and swiftly on the secessionists. Although it has been argued that oil did not cause the war but the pogrom in the north, oil was 'most definitely a stronger contributor' to the declaration of the war. ${ }^{11}$

\footnotetext{
${ }^{7}$ CNN, 24/9/2012

${ }^{8}$ Kenya Minister scraps mining licenses and ups royalties. http://m.bcc.co.uk/news/bus. August 5, 2013.

${ }^{9}$ Id.

${ }^{10}$ Dailey Kate, How to offset your 'conflict minerals' guilt. www.bbc.co.uk/news/m.

11 The earliest oil war, Niger Delta Politics: Dispatches on Security in Nigeria's Oil Region. http://nigerdeltapolitics.word. January 11, 2012.
} 
Thus, in Oil and gas in Africa: Boom or doom? Uche Nwadialor ${ }^{12}$ argues that one of the factors which were enumerated as the causes of the Nigerian civil war was the discovery of oil in the Eastern region and why Biafra declared a Republic was to colonize the oil of the Niger Delta and that the reason why the north fought 'to keep Nigeria one as a task that must be done' was not to lose the oil wealth of the south. Indeed, the period of the Nigerian civil war (1967 1970 ) is often neglected in the analysis of Nigerian oil yet it was during this period that the structures, policies and political relations that created Nigeria's unique version of oil curse were established. The greatest characteristic feature of this curse is opacity; the deliberate obfuscation of information related to oil production, revenues, accounting and operations as governing principle. It is argued that opacity arose from the conclusions reached by the key actors in the conflict (Nigeria, Biafra, the multinationals and their home governments) due to diverse, but strategic reasons to keep oil matters out of the public glare and reckoning even though it was basically for it that the war was prosecuted, lost and won. ${ }^{13}$

This opacity is largely responsible for oil theft and illegal refining in the creeks of the delta. The irony, however, is that having given rise to the scourge of oil theft, illegal refining, sabotage and vandalism, there is beginning to arise strident calls for a reversion to transparency initiatives in oil economic governance. International financial institutions, western governments and non-governmental agencies and even the Jonathan administration are beginning to advocate increased transparency to cure the curse of oil theft and illegal refining focusing on public disclosure of oil-related financial transactions to discourage the misappropriation of revenues and to hold government accountable in order not to give the thieves the 'alibi and claim of right' to engage in the sundry illegalities in the creeks. ${ }^{14}$

It is this call for transparency that informs the basic recommendation of this paper for condonation of the participation of illegal refineries by regulating them, liberalizing the codes for their existence to encourage indigenous participation in the industry to stave off 'theft induced militancy' such that the developing 'rogue economy' may acquire legitimacy and not become a source of conflict between the state, oil companies and the illegal local refiners and their international conspirators. This is largely because, as it appears, the factors that inform and encourage oil theft seem to outweigh the factors in favour of the extermination and bombardment of the developing indigenous technology of which its 'rogue economy' has already taken a firm root to the acknowledgment of sundry stakeholders.

\section{Intrastate Nature of Oil Theft War}

The question is, in what circumstances in empirical history can what is termed illegal become morphed into legal. Are there circumstances which must exist in a social milieu before an economic crime activity can be legalized? If the circumstances exist, are they suitable or comparable to the economic crime of oil theft? It appears not or very slim. The crime of oil

\footnotetext{
${ }^{12}$ Uche Nwadialor, Oil and gas in Africa: Boom or doom? www.vanguardngr.com . August 23, 2012.

${ }^{13}$ US oil companies, the Nigerian civil war and the origins of opacity in the Nigerian oil industry. Journal of American History (2012) Vol. 99, Issue 1. pp. 155 - 165. www.m.jah.oxfordjournals.org. Retrieved on December 2, 2013. 
theft is so varied that state and oil company corruption cannot be condoned. Therefore, the perspective which anticipates indigenous participation and not exclusion is emphasized.

At a more local perspective, the Ibaji communities in Kogi State have been living along the borders of Anambra East and West Local Government Areas and had co-existed peacefully with their neighbours until the commencement of oil exploration by Orient Petroleum Resources Plc believed to be owned by Anambra indigenes. Ibaji people, on whose land the oil is located, alleged an illegal encroachment by Anambra people into their land with a view to taking over their oil-rich fields. The Anambra State Government was believed to have set up a security team comprising soldiers, policemen and vigilante groups to protect the vital area and assets at the refinery. To Awoniyi, ${ }^{15}$ a defender of the Ibaji people, the oil found is in the Odeke area of Kogi State which is being processed by a company owned essentially by Anambra State citizens. This led to the erroneous belief that the oil well is in Anambra State. It is quite clear now that the oil well is in a disputed territory. However, Orient Petroleum Resources Plc is stated to soon commence the production of crude oil at its oil well in Aguleri Otu of Anambra West Local Government Area. For Emeka Anyaoku, Orient has completed acquisition of 7 hectares of land from Kogi State for the establishment of a depot for distribution of petroleum products from the refinery to the north and other parts of Nigeria. ${ }^{16}$

Yet, this local perspective of resource war describes another significant character of the Nigerian oil theft conflicts. It is the grievous intrastate nature of the manifestation of the theft and conflict. Rather than the conflict expressing itself in international colours between Nigeria and the nations of the international community where stolen oil is taken for refinement (mention has been made in this study of so many such nations in the western and eastern European hemispheres not to mention Ghana, Benin Republic, Garbon, Cameroon, Congo, etc which share common international borders with Nigeria and whose nationals have repeatedly been caught pants down in oil theft operations) or between Nigeria and the multinational oil corporations operating within Nigeria, the conflict is between the Nigerian state and its citizens and communities. For instance, in 1993 the operations and activities of Shell alone were disrupted by more than a hundred communal disturbances leading to the loss of some 12 million barrels of crude oil worth about 369 billion naira. ${ }^{17}$

That the Nigerian state is in mutually beneficial joint venture businesses with the 'seven sisters' on wide ranging production sharing contracts in what scholars have called state-corporate complex, and that the Nigerian state approaches the international community with bare pleas of understanding and assistance in the war against the scourge of oil theft which has taken an international slant, as it has admitted, while it bears the cudgels of war against its own people and communities - show the danger and the extent to which there is a disconnect between the Nigerian state and her peoples in the conflict in the delta and which conflict is informing and stoking the fire of religious war in the north. If the war on oil theft is a domestic war, then it has to be added that domestic wars are the worst wars in human history that any nation can illafford. If the war were to be an international one across the borders of Nigeria, chances are it

\footnotetext{
${ }^{15}$ Abu Mike, Kogi-Anambra oil well feud: Between truth and fallacy. www.vanguardngr.com. May 16, 2013. See also, Vincent Ujumadu, 4 killed, 7 injured in renewed clash over oil on Anambra/kogi border. www.vanguardngr.com. Wednesday 23, 2014.

16 Www.google.com/m?q: impartandimpactbusiness. review.blogspot.

17 Akpobibibo Onduku, Environmental conflicts: The case of the Niger Delta. Department of Peace Studies University of Bradford, United Kingdom. www.waado.org. November 22, 2001.
} 
would have been more manageable with lesser casualties unlike a domestic war of the nature under study in which the state is fighting its citizens.

\section{Growing Culture of Agitation}

Increasing global demand for oil has the dual capacity of not only increasing the likelihood of war over the control of major oil exporting regions of the world but a high degree or propensity of increasing oil theft in such regions like the Niger Delta where the three constituent actors of the state, multinationals and the communities are in illegal accord. ${ }^{18}$ Now, there is a permanent and growing culture of agitation that is trailing the theft of oil in the delta. The culture is benefiting from the high level of corruption in the government; the failure of corporate social responsibility from the multinationals; and the palpable resentment in the communities. The culture is also being galvanized by the intellectual world and is assuming a currency of the level that led to the United Nations Resolution 1803 of 1962. It is argued that oil theft is assuming the toga of a drive towards communal control and the rest of the ownership of oil from the state-corporate complex in circumstances in which, prior to 1962, the states of the global south agitated for permanent and sovereign control over natural resources in the decolonization process. If the state and the multinationals currently have a firm grip of the ownership of oil wealth and the communities which are the ultimate owners of the state and businesses have not benefited, what is left for the communities to demand? It is resource control.

The body language and the culture of the agitation of the Movement for the Emancipation of the Niger Delta (MEND), the rainbow coalition of militant groups in Niger Delta, require no further review to grasp the kernel of the message that there is no let-up on the question of communal control of the resources of the delta by its communities. The demand is presently being made in illegalities and criminalities but there is a certain degree and there shall certainly come a time, as the criminalities are unlikely to abate, when what is presently considered a crime may morph into legality. There is no doubt that the curve on the graph of oil theft is on a continuous rise. The curve on the corruption graph of the state is equally going the way of oil theft and the curve of failure of corporate social responsibility on the part of multinationals is the same. If these tendencies remain for a significant long term to come, it can only be submitted that the agitation for communal control may pull through.

\section{Internecine Accusations and Counters}

For instance, in A presidency under siege, the Governor of the Central Bank of Nigeria (CBN) informed President Jonathan of the leakage (theft) of N49.8 billion from oil receipts between 2011 and 2013. The missing amount was $76 \%$ of the total oil receipts into the Federation Account. In concrete terms, the Governor, Mallam Sanusi Lamido, stated that between January 2012 and July 2013, NNPC lifted 594,024,107 barrels of crude valued at $\$ 65,332,350,514.57$ and repatriated only $\$ 15,528,410,098.77$ representing $24 \%$ of the value and therefore failed to repatriate $\$ 49.804$ billion. ${ }^{19}$ Granted that the $\mathrm{CBN}$ has the foregoing revelation of leakage against the NNPC in 2013 which was vehemently refuted thereafter by the state, way back in

\footnotetext{
18 Jeff Clogan, Oil and revolutionary governments: Fuel for international conflicts. Princeton University. http://nwo8.american.edu. Retrieved on December 12, 2013.
}

${ }^{19}$ Emmanuel Aziken, A presidency under siege. www.vanguardngr.com. December 18, 2013. 
ISSN: 2689-5102

Volume 4, Issue 1, 2021 (pp. 70-84)

1999 the NNPC had accused the Joint Venture Partners (multinationals) of neglecting the welfare of the communities adding that they had failed over the years to develop any industry standards towards community development and achieving any peaceful coexistence with the communities. $^{20}$

Yet, by 2002 the multinationals hit back at NNPC. M. Wink, a General Manager of Shell, in Shell: A model in partnership stated: 'It is not our role to develop the communities. We cannot take upon ourselves the role of the government to develop those communities. We are not the government. ${ }^{21}$ What is left for the communities to demand is clear and bare. If on December 14, 1962 the United Nations granted the states of the global south the right to permanent sovereignty over their natural resources, and five decades later the right is not exercised in favour and benefit of the communities on which ultimate sovereignty resides, the call by the militants for a further transfer of the right to the communities may seem due. Okah Henry, a scion of MEND, once stated to Yar'Adua administration, 'We would die as free men than live as peaceful slaves. Yar'Adua must do what is right and give us not just what we demand but what is just. He must return our lands and dignity after which words like amnesty will make meaning to us. ${ }^{22}$ In terms of practical strategy, Agele-Oba of MEND ${ }^{23}$ has stated, 'You can see a change in our tactics to our struggle of recent. Before now, it used to be kidnapping expatriates working with the multinationals and you see the dimension it is taking today is launching major attacks on oil installations in the region and beyond'. Now, by 2013, it has added oil theft.

\section{Oil Theft as Threat}

Oil theft has been identified as the greatest threat to the Nigerian economy. The menace incidentally is as old as the industry dating back to the 1960s and 1970s, though it took an upward, epidemic swing in the early 1990s because of the tensions and dissensions between foreign multinational companies and communities over resource control leading to the militarization of the Niger Delta. ${ }^{24}$ It has been going on for long in the creeks of Ogoni communities and other swamps of the Delta. What is new is that the crime has assumed

\footnotetext{
${ }^{20}$ Uwugiaren, I., Your approach is wrong. The News Magazine, August 30, 1999 p. 36. See also, Okwelum C.O., Legal issues in corporate social responsibility code in selected oil rich areas in Nigeria, Nigeria Journal of Education, Health and Technology Research. Vol. 1 No. 2 May, 2011p. 61.

${ }^{21}$ Wink M., Shell: A model in partnership. Tell Magazine. January 14, 2002 p. 41. See also, Okwelum C.O., Legal issues in corporate social responsibility code in selected oil rich areas in Nigeria, Nigeria Journal of Education, Health and Technology Research. Vol. 1 No. 2 May, 2011 p. 61.

${ }^{22}$ Amaize Emma, Why Okah'll forever remain suspicious. Vanguard Newspares, July 17, 2009 p. 38. See also, Okwelum C.O., Movement for the Emancipation of the Niger Delta (MEND) and legal issues in Amnesty: For freedom or for justice? Nigeria Journal of Education, Health and Technology Research. Vol. 2 No. 1 December, 2011 p.230.

${ }^{23}$ Ochayi N., Bombing of oil installation to continue until? Vanguard Newspaper. July 20, 2009 p. 10. See also, Okwelum C.O., Movement for the Emancipation of the Niger Delta (MEND) and legal issues in Amnesty: For freedom or for justice? Nigeria Journal of Education, Health and Technology Research. Vol. 2 No. 1 December, 2011 p.227.

${ }^{24}$ Adebisi Yemi, Review: From rebellion, insurgency to belligerency, the Niger Delta oil war in international war. www.legaloil.com. June 4, 2011. Ovuozorie Macauley, Determination, the driving force to curbing oil theft in Nigeria. www.legaloil.com. http://www.channelstv.com/home/. July 31, 2013.
} 
ISSN: 2689-5102

Volume 4, Issue 1, 2021 (pp. 70-84)

stratospheric dimensions since President Jonathan assumed the presidency. ${ }^{25}$ According to the President himself, the problem has started long ago and if previous governments had done something to check it, it would not have developed into the level it has now. Now, people within and outside the country are involved in the crime and its impact are environmental degradation; loss of revenue; increased criminality; lack of security and the infiltration of international collaborators and bad image for the country. ${ }^{26}$

Yet, the President did not, until recently when he advocated for electronic surveillance, ${ }^{27}$ outline any practical measures being put in place to check it showing lack of political will to combat the scourge. Rather, the President stated that it is 'embarrassing that it is only in Nigeria that crude oil is stolen'. Granted that it is true that it is only in Nigeria that crude oil is stolen, analysts have alleged that the President has ignored the stolid fact that it is only Nigeria that harbors the greatest percentage of the gravely improvised populace even as a tiny minority has cornered the entire enormous commonwealth of the nation to its pocket. ${ }^{28}$ Before now, states' and oil companies' response to the hydra-headed scourge had been jack boot military offensive and smash-down. However, Anthony Ogbuigwe ${ }^{29}$ suggests the need to develop a national plan for the protection of critical assets and a declaration of the pipelines as critical assets.

For Orji Uzor Kalu in The oil crisis in Nigeria, recrudescence of the phenomenon of oil theft and refining is the bane. The President's pledge to crack down on oil theft fails because no sooner is one hole on a pipeline shut or one illegal distillery closed down than two others arise in their places and over a three week period, the Navy blocked 600 illegal distilleries, only to find that 400 new ones had been established around them. ${ }^{30}$ In other words, the bush refinery has makeshift equipment and is easy to install: 'If you destroy one refinery; in a few hours, another one is set up. ${ }^{31}$ In fact, whosoever wants to deal with oil theft, as counseled by Ademola-Olateju, should better be prepared to die because the racketeering is on an industrial scale. $^{32}$

\section{Percentage Distributions}

One of the areas in which so much controversy brews in the discourse and literature of oil theft and illegal refining is in percentage distribution both of the oil produced and the oil stolen. Both of the oil legally refined and the oil illegally refined. Two tendencies appear to emerge from the research records: firstly is the one which tends to underestimate the proportion of the theft and refining business and thereby underscore its impact on the economy. The other is the

\footnotetext{
${ }^{25}$ Ademola-Olateju Bamidele, Oil theft: The fleecing of Nigeria. http://premiumtimesng.com. See also, Audu Liberty Oseni, Special Report: Crude refining in Niger Delta communities. www.westafricainsight.org. January, 2013.

${ }^{26}$ Emeka Alex Duru. Addressing oil theft, illegal bunkering in Niger Delta. http://dailyindependentnig.com. August 26, 2013.

${ }^{27}$ David Mark, Oil theft: FG to use electronic pipeline surveillance. www.vanguardngr.com. October 26, 2013.

${ }^{28}$ Onwubiko Emmanuel, Crude oil thieves, subsidy thieves and a battered nation. www.thenigerianvoice.com. July 25, 2012.

${ }^{29}$ Asu Femi, Clamping down on crude oil theft, pipeline vandalism. http://businessdayonline.com. October 3 , 2013.

${ }^{30}$ Orji Uzor Kalu, The oil crisis in Nigeria. www.diplomaticourier. October 10, 2013.

${ }^{31}$ Nwakamma Nathan, How to check oil theft, illegal refineries in the Niger Delta. http://thenationonlineng.net. April 25, 2013.

${ }^{32}$ Ademola-Olateju, Loc. Cit.
} 
tendency to overestimate the proportion involved and thereby over-score its impact on the economy. The earlier tendency equally tries to rationalize and decriminalize the phenomenon while the later condemns and criminalizes it. The first tendency is usually empathetic and purveyed by ex-statesmen, non-state agents and actors and by extension, militants while the second tendency is propounded by state actors and oil company agents and by extension, community leaders.

The first tendency does not necessarily believe that oil theft and illegal refining cannot be accommodated but rather, it believes that it can be reformed legally and technologically while the other confronts it with condemnation, military offensives and criminal prosecutions. From the law books, government's and oil company's perspectives, oil theft in all its ramifications borders on criminality and economic sabotage. In fact, it is the 'new face of terrorism. ${ }^{33}$ But in the local communities in the Niger Delta, the perception is entirely different: it is a 'display of local expertise' ${ }^{34}$ and an entrepreneurial free market response to local economic dysfunction, chronic energy shortages, and government's failure to deliver on basic public services. ${ }^{35}$ Residents of the Delta believe that lack of development and environmental devastation has given them an entitlement to help themselves to a share of the vast oil wealth of the region. ${ }^{36}$

This divergence is why, for instance, right activist, Ninmmo Bassey ${ }^{37}$ believes that bad as bush refineries are, they are not at the heart of the oil theft menace. For Orji Uzor Kalu, an exgovernor, although the illegal refineries only make up for a small portion of the theft, their environmental impact is vast. Majority of the theft is on a larger scale when coordinated groups of workers of oil multinationals tap into infrastructures siphoning crude into barges before transporting them into larger crafts for refining in volatile 'firewood' distilleries offshore. ${ }^{38}$

For the second tendency, the full extent of the nation's larcenous ingenuity is on display in oil thievery. ${ }^{39}$ Nigeria represents the face of brazen oil theft; an organized crime with international reach. Other than drug trafficking, no other illegal trade is more lucrative. ${ }^{40}$ Adam Nossiter ${ }^{41}$ submits that 'working in elaborate networks and protected by corrupted security officials, oil thieves tap into the huge and isolated networks of pipes that crisscross the nation's swampy southern Niger Delta' and declaring it an 'emergency', the Ribadu Committee set up by the Presidency submitted that over the preceding decade, thieves had been stealing $6 \%$ to $30 \%$ of

\footnotetext{
${ }^{33}$ Alison-Madueke, Oil theft, another face of terrorism. www.vanguardngr.com. October 29, 2013.

${ }^{34}$ Biakpara Peter, No illegal refineries in Niger Delta but local expertise. www.vanguardngr.com. September 16 , 2012.

35 SDN Report: Communities not criminals - Illegal oil refining in the Niger Delta. www.stakeholderdemocracy.org. October 16, 2013.

${ }^{36}$ Emeka Alex Duru, Addressing oil theft, illegal bunkering in Niger Delta. http://dailyindependent.com. August 26, 2013.

37 Nigeria prepares to prosecute 500 detained oil thieves. $\underline{\text { www.legaloil.com. }}$ http://www.chiagotribune.com/news/ July 18, 2013.

38 Orji Uzor Kalu, The oil crisis in Nigeria. www.diplomaticourier. October 10, 2013.

${ }^{39}$ Adam Nossiter, As oil thieves bleed Nigeria, Report says, Officials profit. www.energytribune.com. September 25, 2013.

40 John Vidal, F1bn a month: The spiraling cost of oil theft in Nigeria. www.theguardian.com. October 5, 2013; Ademola-Olateju Bamidele, Oil theft - The fleecing of Nigeria. http://premiumtimesng.com. (ND)

${ }^{41}$ Adam Nossiter, Loc. Cit.
} 
the nation's daily production and hydrocarbon theft is a major source of loss of revenue to the Federal Republic of Nigeria.

Corroborating the enormity of the crime, Tope Adeboboye in How oil thieves wreck havoc on the Niger Delta underscores the alarmist state actors' view that oil is the nation's major export fetching millions of dollars each day but 'sadly, the same resource is being savagely stolen in copious quantities on daily basis and if left unchecked, it would plunge the country into a major economic quagmire pretty soon. ${ }^{4}$

\section{Critical and Orthodox Scholarships}

These two tendencies have found expressions and representatives in Paul Collier of the orthodox 'greed not grievance' scholarship and Joe Sutcliffe of the critical 'petro-capitalist' school. ${ }^{43}$ The debate of the 'greed not grievance' school which bodes completely with the perspective of the state and oil companies suggests that oil theft and illegal refining is a rebellion driven entirely by economic greed: the wish to gain access to resource wealth and the clientelist rents commonly connected to natural resources. Such behaviour is evidenced in the predatory economic activities seen among militants, often standing starkly at violent odds with their professed grievances of political and economic marginalization. The school refers to youth militants, oil thieves and refiners as mass criminal groups offering only an ideological façade of political grievances and concern for communities. It portrays militants as bandits and gangsters whose actions are based on greed and criminality utilizing violence for aims of personal economic enrichment whilst simultaneously offering youth militants no analytical attention as an important political factor considering only their agency role in relation to economic predation. ${ }^{44}$ The 'greed not grievance' scholarship is more or less a labelling theory whereby the criminal act of oil theft helps label youths as militants, delinquents and outcasts.

The critical 'petro-capitalist' school considers Nigeria as a petro-state with a political economy that is imbricated in an oil-complex economy. An economy that is so reliant on oil rents that it does not need the tax of its citizens in order to provide social amenities; yet these amenities are not provided but building an army of internal repression in collaboration with multinationals is preferred. This perspective is situated within a radical scholarship which critiques the 'greed not grievance' perspective and its orthodoxy among many policymakers which attempts to undermine that which is indigenous as crude, criminal and unacceptable. It contributes to a wider intellectual project which attempts to introduce the development of indigenous technology as one of the issues thrown up in the phenomenon of illegal refining and oil theft in the Niger Delta. ${ }^{45}$

The critical scholarship anchored by M. Watts in Righteous oil? Human rights, the oil complex and corporate social responsibility ${ }^{46}$ argues that petro-capitalism is built on radical fiscal centralism whereby the Federal Government has increasingly controlled oil wealth with a

\footnotetext{
${ }^{42}$ Tope Adeboboye, How oil thieves wreck havoc on Niger Delta. http://sunnewsonline.com/news. August 23, 2013.

${ }^{43}$ Joe Sutcliffe, Military in the Niger Delta: Petro-Capitalism and the politics of youth. www.e-ir.info/2012/06. June 25, 2012.

${ }^{44} \mathrm{Id}$.

$45 \mathrm{Id}$.

${ }^{46}$ Watts, M., (2005), Righteous oil? Human rights, the oil complex and corporate social responsibility. Annual Review of Environment and Resources. 30, 373 - 407. Cited in Joe Sutcliff. Id.
} 
derivation formula dropping from $50 \%$ to $3 \%$ from 1966 to the 1990 s and recovering to $13 \%$ only by 1999 . With a bout of the statutory trinity in the Petroleum Act of 1969, the Land Use Act of 1978 and the Constitution of the Federal Republic of Nigeria 1999, the central government has rallied all oil and land ownership to itself and dislodged, distorted and stultified all local and indigenous claims.

In the process, the central government has propped up a firmly rooted petro-state with $90 \%$ of its revenue coming from oil and the gains distributed by a 'fat-cat-government' through clientelist networks, enriching a small elite group and perpetuating corruption. This petro-state arising from this petro-capitalism is part of an 'oil complex' used to signify the broader institutional structure surrounding the political economy of oil; the members of which are: the state, the oil companies, state and private security apparatuses, foreign military interests in regional oil wealth such as US-backed Africom. It is within this 'oil complex' that the struggle and competition over oil rent, oil theft and illegal refineries take place. ${ }^{47}$

The greatest significant point in the critical perspective literature which attacks the 'greed not grievance' school of under-highlighting is the utter lack of developmental benefits gained by the people, the ethnic oil minorities who suffer most, the worst consequences of oil extraction which deprivation it admits, informs rebellion and belligerence. It argues that militancy in theft and illegal refineries is invoked not only against the multinationals, the state and community elders but also must be understood as an attempt to address social injustice as well as a mode of production and a way of making a living throwing up an indigenous technology from the womb of illegality and criminality. ${ }^{48}$ This has been characterized by Yinka Omorogbe as a 'rogue economy'.

\section{Convergence of Opinion}

A commonality of opinion however seems to exist in both tendencies to the effect that the military and staff of the multinationals which are in charge of curbing the scourge are involved in the menace. To Ademola-Olateju, so much oil is being stolen by the Nigerian National Petroleum Corporation (NNPC) under the guise of feeding local refineries in addition to several thousands of barrels stolen by the rich and powerful under the protection of the military. ${ }^{49}$

Therefore, it is not only dishonest for the government and the oil companies to blame the poor for stealing the oil but also criminal. The face of the jerry-can-wielding-rural-poor is not the face of oil theft. They are the foot soldiers paraded before the public as a decoy and deceit. Oil theft is a big criminal ring with sophisticated organizations and international networks. Ademola-Olateju asks: Where would the poor have the millions to purchase or hire vessels, bribe customs and procure military cover for their operations? 'Oil theft is not for the poor, it is an extensive racket involving the military, security apparatchiks, politicians, dubious industrial moguls and the oil companies. ${ }^{50}$

The well founded and substantiated allegation that the oil companies are complicit in the stealing of oil is, for any other reason, based on the indisputable fact that the Federal Republic

\footnotetext{
${ }^{47} \mathrm{Id}$.

${ }^{48}$ Joe Sutcliffe, Military in the Niger Delta: Petro-Capitalism and the politics of youth. www.e-ir.info/2012/06. June 25, 2012.

${ }^{49}$ Ademola-Olateju Bamidele, Oil theft - The fleecing of Nigeria. http://premiumtimesng.com. ${ }^{50} \mathrm{Id}$.
} 
of Nigeria, the seven sisters and even the emerging independent local content vehicles do not know how much oil they produce. ${ }^{51}$ Indeed, Nigeria's oil revenue account is one of the most secret of mysteries, made even more so by a most secretive administration whose executive authority is so wide-ranging that it can afford to play God on the matter. The Ayo Irikefe Commission of Inquiry into the missing N2.8 billion set up by the Shagari against the Obasanjo administration, and the Pius Okigbo Panel of Inquiry into the oil windfall from the Gulf war in 1990 set up by the Abacha against the Babangida administration, were all eaten up by aura of deep and effulgent corruption. Same corruption is currently trailing the Jonathan administration over the withdrawal of \$5billion out \$9billion from the 'excess crude account' ${ }^{52}$

The tendency is patently clear that when it suits the 'state oil complex' to inflate the quantity stolen in order to magnify the enormity of the scourge and justify the need for deploying the armed forces of the republic to storm the delta against the 'oil thieves and illegal refineries', it gladly does so. When it suits it to minimize the quantity stolen in order to attenuate the adverse publicity it exposes the industry internationally and collaterally and in order to attract direct foreign investment and underwritings it will gleefully do so. Yet, it does not suit the state to liberalize and deregulate the sector to attract local private initiatives in refining business until recently after a failed attempt.

\section{Resolving Opacity?}

Addressing this knotty issue, Asisi Asobie has canvassed that if combined metering at the wellhead and at the flow stations, the inlet to the terminals and outlet are accurately recorded, it may be possible to know not only precisely how much oil is produced but more importantly, how much oil is lost. All that is going round is estimation. All the relevant stakeholders do not know exactly what is being produced and what is being lost in the state. Asobie declares: If we do not know what is produced at the wellhead or at worst, the flow-station, and then find out how much is expected and the difference, nobody can claim to know how much is produced or how much is stolen. ${ }^{53}$

In fact, this opacity was long highlighted negatively in the classified Pearson Report in the US as far back as 1966 which was commissioned to assess the impact of increased oil revenues in Nigeria. The report revealed that the official Nigerian government statements concerning the anticipated Nigerian oil revenues were substantially lower than what the oil company officials knew could be forecasted and that both these projections were lower than the figure estimated by oil field operators. The report concluded that these may in due course have 'extremely explosive results' and in 2014, the chicken came home to roost with monumental conflicts resulting in oil theft and illegal refineries in the creeks. ${ }^{54}$

\footnotetext{
${ }^{51}$ Ademola-Olateju Bamidele, Oil theft - The fleecing of Nigeria. http://premiumtimesng.com.

${ }^{52}$ Obi Nwakanma, The oil revenue mystery. www.vanguardngr.com. December 1, 2013.

${ }^{53}$ Olayinka Collins, Nigeria is oil dependent, not oil-rich, says Asobie. www.ngrguardiannews. October 16, 2013.

${ }^{54}$ US oil companies, the Nigerian civil war and the origins of opacity in the Nigerian oil industry. Journal of American History (2012) Vol. 99, Issue 1. pp. 155 - 165. www.m.jah.oxfordjournals.org. Retrieved on December 2, 2013.
} 
ISSN: 2689-5102

Volume 4, Issue 1, 2021 (pp. 70-84)

www.abjournals.org

\section{CONCLUSION AND RECOMMENDATIONS}

In the legal discourse of the resource curse of oil theft and illegal refineries in Nigeria, two dominant but mutually repugnant perspectives have emerged. The first is orthodox in that it is mainly advanced by the State, its actors and the industry calling for their annihilation and the prosecution of those involved while the other is advanced by non-State actors, militants and critical writers calling for their legitimization, regulation and recognition. These have made the issue of recommendation of the solution to the curse controversial and inconclusive or partisan. However, given the nature of the importance of the sector to the national economy and the failures of the State and industry in infrastructural development and corporate social responsibilities, the perspective of non-State actors appears more acceptable as that can lead to the inclusion and the participation of indigenous communities in the economic activity which has hitherto been the exclusive preserve of the State and the industry. The perspective equally tallies with the broader issue of the liberalization of the sector and discounts and underplays the use of military force in the suppression of an attempt of a people in the struggle for economic participation and survival.

\section{REFERENCES}

[1] Adam Nossiter, As oil thieves bleed Nigeria, Report says, Officials profit. www.energytribune.com. September 25, 2013.

[2] Adebisi Yemi, Review: From rebellion, insurgency to belligerency, the Niger Delta oil war in international war. www.legaloil.com. June 4, 2011.

[3] Ademola-Olateju Bamidele, Oil theft - The fleecing of Nigeria. http://premiumtimesng.com.

[4] Abu Mike, Kogi-Anambra oil well feud: Between truth and fallacy. www.vanguardngr.com. May 16, 2013.

[5] Akpobibibo Onduku, Environmental conflicts: The case of the Niger Delta. Department of Peace Studies University of Bradford, United Kingdom. www.waado.org. November 22, 2001.

[6] Alison-Madueke, Oil theft, another face of terrorism. www.vanguardngr.com. October 29, 2013.

[7] Amaize Emma, Why Okah'll forever remain suspicious. Vanguard Newspapers, July 17, 2009 p. 38.

[8] Asu Femi, Clamping down on crude oil theft, pipeline vandalism. http://businessdayonline.com. October 3, 2013.

[9] Audu Liberty Oseni, Special Report: Crude refining in Niger Delta communities. www.westafricainsight.org. January, 2013.

[10] Biakpara Peter, No illegal refineries in Niger Delta but local expertise. www.vanguardngr.com. September 16, 2012.

[11] CNN, 24/9/2012

[12] Dailey Kate, How to offset your 'conflict minerals' guilt. www.bbc.co.uk/news/m.

[13] David Mark, Oil theft: FG to use electronic pipeline surveillance. www.vanguardngr.com. October 26, 2013. 
African Journal of Law, Political Research and Administration

ISSN: 2689-5102

Volume 4, Issue 1, 2021 (pp. 70-84)

www.abjournals.org

[14] David S. Painter, Oil and the American century. The Journal of American History, Vol. 99, Issue 1 June 2012. www.m.jah.oxfordjournals.org. Retrieved on December 2, 2013.

[15] Emeka Alex Duru, Addressing oil theft, illegal bunkering in Niger Delta. http://dailyindependent.com. August 26, 2013.

[16] Emmanuel Aziken, A presidency under siege. www.vanguardngr.com. December 18, 2013.

[17] Kenya Minister scraps mining licenses and ups royalties. http://m.bcc.co.uk/news/bus. August 5, 2013.

[18] Jeff Clogan, Oil and revolutionary governments: Fuel for international conflicts. Princeton University. http://nwo8.american.edu. Retrieved on December 12, 2013.

[19] Joe Sutcliff, Military in the Niger Delta: Petro-Capitalism and the politics of youth. www.e-ir.info/2012/06. June 25, 2012.

[20] John Vidal, F1bn a month: The spiralling cost of oil theft in Nigeria. www.theguardian.com. October 5, 2013.

[21] Nigeria prepares to prosecute 500 detained oil thieves. www.legaloil.com. http://www.chiagotribune.com/news/ July 18, 2013.

[22] Nwakamma Nathan, How to check oil theft, illegal refineries in the Niger Delta. http://thenationonlineng.net. April 25, 2013.

[23] Obi Nwakanma, The oil revenue mystery. www.vanguardngr.com. December 1, 2013.

[24] Ochayi N., Bombing of oil installation to continue until? Vanguard Newspaper. July 20, 2009 p. 10.

[25] Okwelum C.O., Legal issues in corporate social responsibility code in selected oil-rich areas in Nigeria, Nigeria Journal of Education, Health and Technology Research. Vol. 1 No. 2 May 2011 p. 61.

[26] Okwelum C.O., Movement for the Emancipation of the Niger Delta (MEND) and legal issues in Amnesty: For freedom or for justice? Nigeria Journal of Education, Health and Technology Research. Vol. 2 No. 1 December 2011 p.230.

[27] Olayinka Collins, Nigeria is oil-dependent, not oil-rich, says Asobie. www.ngrguardiannews. October 16, 2013.

[28] Onwubiko Emmanuel, Crude oil thieves, subsidy thieves and a battered nation. www.thenigerianvoice.com. July 25, 2012.

[29] Orji Uzor Kalu, The oil crisis in Nigeria. www.diplomaticourier. October 10, 2013.

[30] Osita Obierika, Geopolitics and strategy of petroleum. The Nigerian experience. www.vanguardngr.com September 27, 2012.

[31] Ovuozorie Macauley, Determination, the driving force to curbing oil theft in Nigeria. www.legaloil.com. http://www.channelstv.com/home/. July 31, 2013.

[32] SDN Report: Communities not criminals - Illegal oil refining in the Niger Delta. www.stakeholderdemocracy.org. October 16, 2013.

[33] The earliest oil war, Niger Delta Politics: Dispatches on Security in Nigeria's Oil Region. http://nigerdeltapolitics.word. January 11, 2012.

[34] The paradox of plenty, Niger Delta Politics: Dispatches on Security in Nigeria's Oil Region. http://nigerdeltapolitics.word. January 10, 2012.

[35] Tope Adeboboye, How oil thieves wreak havoc on Niger Delta. http://sunnewsonline.com/news. August 23, 2013.

[36] Uche Nwadialor, Oil and gas in Africa: Boom or doom? www.vanguardngr.com. August 23, 2012. 
African Journal of Law, Political Research and Administration

ISSN: 2689-5102

Volume 4, Issue 1, 2021 (pp. 70-84)

www.abjournals.org

[37] US oil companies, the Nigerian civil war and the origins of opacity in the Nigerian oil industry. Journal of American History (2012) Vol. 99, Issue 1. pp. 155 - 165. www.m.jah.oxfordjournals.org. Retrieved on December 2, 2013.

[38] Uwugiaren, I., Your approach is wrong. The News Magazine, August 30, 1999 p. 36.

[39] Watts, M., (2005), Righteous oil? Human rights, the oil complex and corporate social responsibility. Annual Review of Environment and Resources. 30, 373 - 407.

[40] When oil helps and when oil hurts. Niger Delta Politics: Dispatches on Security in Nigeria's oil Region. http://nigerdeltapolitics.word. January 11, 2012.

[41] Wink M., Shell: A model in partnership. Tell Magazine. January 14, 2002 p. 41.

[42] Www.google.com/m?q: impartandimpactbusiness. review. blogspot. 